\title{
An Introductory Guide in Marine Propulsion and Green Shipping
}

\author{
M. Tsikouras \\ Dept. of Industrial Design \\ and Production \\ Engineering \\ University of West Attica, \\ Athens, Greece
}

\author{
M. Papoutsidakis \\ Dept. of Industrial Design \\ and Production \\ Engineering \\ University of West Attica, \\ Athens, Greece
}

\author{
D. Papachristos \\ Dept. of Industrial Design \\ and Production \\ Engineering \\ University of West Attica, \\ Athens, Greece
}

\author{
N. Nikitakos \\ Dpt. of Shipping trade \& \\ Transport \\ University of Aegean, \\ Greece
}

\begin{abstract}
In this elementary work, all major aspects of marine propulsion and green shipping are going to be presented. It is the primary work that will be followed by experimental simulations in fuel consumption and the way that could be reduced in an attempt to adopt the "green" terminology in all shipping procedures.
\end{abstract}

\section{Keywords}

Electrical Propulsion, renewable energy, marine systems, autonomous systems, green shipping

\section{INTRODUCTION}

People from ancient times until today have the necessity of traveling long distances for many reasons. One of the biggest, if not the biggest, obstacle is the sea, which man has to overcome by any means. The oldest way to travel overseas is via ship, which was invented when man noticed that the wood floated on the surface of the sea, the buoyancy. So everything started from a simple law of physics, which lead to a revolutionary change in everyday life. Nowadays man has managed to ensure safe travel via sea for himself as well any commodity he wished to transport. Thus, many different types of ships had to be designed to cover each individual category of goods. Every type of ship fulfils different kind of needs that people have. The driving force of a ship is the main engine which is powered by different types of fuel. That's the reason we are going to delve into the features of the main engine and analyze the types of fuel. As the years go by and the greenhouse effect is getting more intense, people explore new, eco friendly ways to arrange their transportations. We will analyze many of them in the following sections.

\section{ELECTRICAL PROPULSION}

The electrical propulsion defined as the procedure of a marine engine which main axes are moving with electric engines without any other type of engine (example : diesel). Conventional engines are parts of the ships but they are not moving the main axis directly. They are suppling electric generators which produce electricity for main electric engines in order to move the main axe. The whole installation contains many control systems keeping the propulsion stable. The most important levels are the engine start, the increase -decrease of rounds per minute and the direction change of revolution on the electrical engines.

The following definitions are very important to know about the electrical propulsion:

F.E.P. (Full Electric Propulsion)

\section{A.E.S. (All Electric Ship) \\ P.N. (Propulsion Network)}

S.S.S. (Ship Service System).

The first applications which the propulsion supplied by electricity arranged with Direct Current (DC) which is still used by many ships up to today regardless of the engine type. Nowadays we are using synchronous motors with performance level over $96 \%$, which is $4 \%$ higher than the asynchronous motors with normative voltage 3,3 until 6,6 $\mathrm{kV}$.

There are two kinds of sync motors:

1. Permanent Magnet

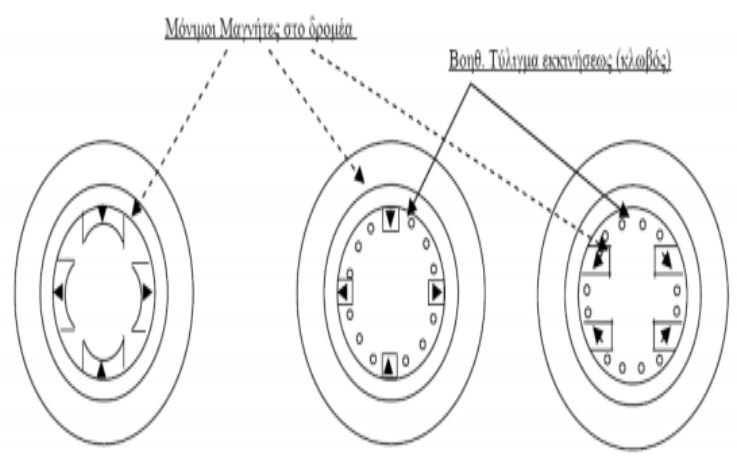

Fig1 : Layout of sync motors with Permanent magnets

2. Alternating current
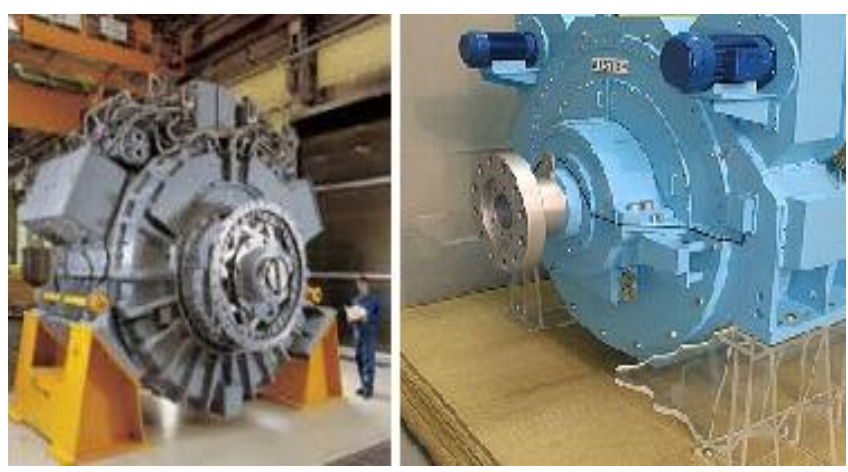

Fig 2: On the left picture is PERMASYN motor powered by SIEMENS. On the right picture is AIM motor powered by ALSTOM

I.F.E.P (Integrated Full Electric Propulsion) 


\section{Advantages of electric propulsion systems}

- The range of ship and shaft rotation is $0 \%$ until $100 \%$.

- Response time is very short.

- Noises and vibrations are limited.

- One of the most important advantages is the fuel economy, because there is an option which you can choose the shaft you want to work and the number of the round per minutes.

- $\quad$ Space saving.

- Electric propulsion systems are easier to install.

- Reliable function and safety.

\section{Disadvantages of electric propulsion systems}

- Extremely high installation cost

\section{MARINE ENGINES}

Referring to the marine engines there is the following innovations:

Two types of fuel usage. Through this innovation there is reduction of Nox (Nitrogen oxides air pollution) and shipping companies comply with the rules of IMO (International Maritime Organization)-Tier III. Basically marine engines consume two fuels. The consume LNG coupled with bio-fuel or Marine Deisel Oil (MDO) or Heavy Fuel Oil (HFO). Main Advantage is the quick change of fuels on operating time, without performance loss

Retrieval system and usage of lost heat. Comparing the performance with fuel consumption on a two stroke engine we will ascertain that consumption fluctuate on a good level. The performance is able to be increased taking advantage of gas pollutant. So there is a system which absorbs the heat from the exhaust fumes and it transform them in electricity. This electricity sub serve one electric engine, or get used for the rest operations on the vessel.

Engine Supply with LNG fuel. LNG is a mixture of liquefied natural gas with diesel. Consuming this fuel we decrease the gas pollutant emission and we reach better fuel consumption. Also really important is that we decrease carbon dioxide until $30 \%$ comparing with diesel fuel.

Mixture of water and fuel. During the fuel combustion, elaborating high temperatures which increase the level of nitrogen oxide. Therefore decreasing temperature, we reach less nitrogen oxide emissions. One way to arrange this temperature reductions is mixing water with the fuel. This is because of the evaporation of the water into the combustion chamber, where the temperature and the nitrogen oxide get increased.

Special filters for fuel filtering. The filters which filtering the exhaust fumes EGS (Exhaust Gas Scrubber) have been introduced into the market, in order to decrease the SOx emissions.

\section{RENEWABLE ENERGY}

Regarding the investigational renewable energy sources there are the following sections:

Biofuel \& nuclear energy: Biofuels are a wasted products category, but they could be created from various human labors - activities. This type of fuels are liquid - solid - gaseous form and they are the newest type of fuel. Thinking the ecological and economical advantage, shipping companies looking forward to import the biofuels into the marine. The following are the biofuel categories :

Biodiesel

Bioethanol

Biogas

Biomethanol

Biodimethylether

Clear vegetable oil

One more driving force for the marine propulsion is the nuclear energy. There are fighting vessel which are moving with nuclear energy, but because of public disaffection, these vessels don't preferred.

Fuel Cell. Fuel cells have been used for many years and they have proved to have a good performance, but there aren't full applications on marine industry. The reason is some safety problem, which shipping companies will face. Therefore scientists arrange simulations in order to import this high performance technology into the marine market.

Wind Energy. Wind energy could be produced only taking advantage of the wind. The most characteristic example of wind energy is the sailing boats which move relying entirely on the wind. This type of energy is considered as the best driver, because it doesn't costs nor pollutes.

Solar Energy. Using the solar energy we recognize that we are consuming less energy. This could be achieved with the installation of panels which harvest the solar power. These panels get installed at the free space on the top of the vessels. Many small vessels are using these panels. Solar and wind power is free of charge and endless, that's the reason why scientists will invest in these types of power for many years.

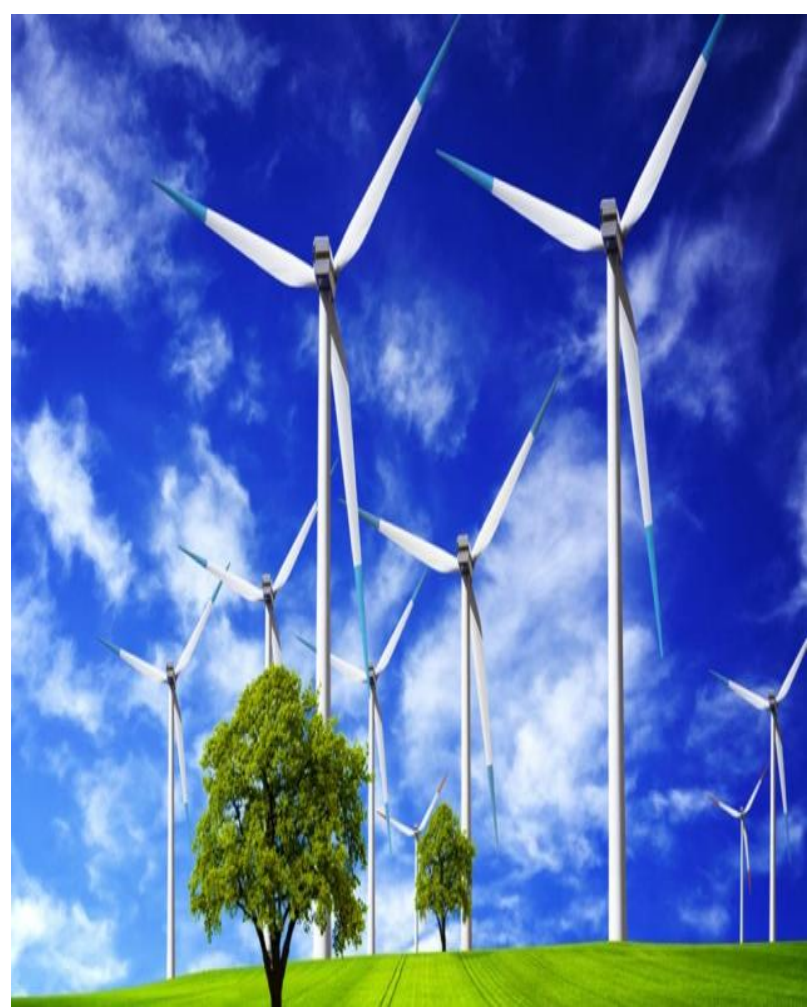




\section{GREEN VESSELS}

The range of the secondary equipment concerning shipping has risen because of the increasing requirements of shipping companies. The energy and fuel saving systems, the use of alternative fuel, etc. are innovative technologies that have been created exactly for this purpose. Nowadays in order to purchase a vessel secondary equipment is one of the main criteria. Due to marine legislation many of new technologies appeared, because of the SOx , NOx and $\mathrm{CO} 3$ emission limitations. Therefor the main reason the technologies get installed into the vessels is the fuels saving.

\section{CONCLUSION}

Green Shipping is the future of maritime and this indisputable, since we observe the damages caused to the environmental from all these years of lack of environmental protective laws. Purchasing a green vessel is much more expensive than purchasing a compact vessel, but there are advantages that assure that the shipping company will be depreciated. The rules of IMO will be a key factor, because all the shipping companies are purchasing according to these rules. Making these regulations tougher, automatically rules out many vessels which are less environmental friendly and push shipowners to purchasing new vessels more environmental friendly. On the other hand IMO should award the shipping companies with green fleets in order to give the motivation for more environmental friendly maritime.Most times human error is solely responsible for enormous environmental disasters and the main cause is the crew being unaware for the environmental consequences of their actions. Therefore the vessel's crew and harbor masters should raise their ecological awareness. Every state should invest a major amount of founds in order to create new eco-friendly facilities.

In conclusion, our proposal toward all the relevant authorities, is to promote and found the green ideas that will direct shipping companies to turn to eco friendly solutions which will benefit the environment and provide terms to provoke ship owners to purchase green vessels. The future of shipping and consequently the future of the entire environment will be defined by this kind of initiatives.

\section{ACKNOWLEDGMENTS}

All authors would like to thank the University of West Attica and specifically the Post Graduate Program of Studies (MSc)
"New Technologies in Shipping and Transport", for the financial support provided to them to undertake this research project.

\section{REFERENCES}

[1] http://www.tufinc.com/marine-azimuth-thruster-2.html

[2] https://www.wartsila.com/encyclopedia/term/azipod(azimuthing-podded-drive)

[3] Patel M. R. (2012). Shipboard Propulsion, Power Electronics and Ocean Energy. pp. 254

[4] Green Ship of the Future (2009) "Green Ship magazine" pp. 7.

[5] http://www.ecomarinepower.com/en/wind-and-solarpower-for-ships

[6] Khoo, Y. K. K., \& Ölçer A. İ. (2011). "Life-cycle impact analysis of green ship design/operation alternatives based on environmental and monetary aspects". International Conference on Technologies, Operations, Logistics and Modelling for Low Carbon Shipping, (LCS 2011), 22-24 Iovvíov, Г $\lambda \alpha \sigma \kappa o ́ \beta \eta, ~ U K$

[7] www.polb.com/greenship.

[8] http://www.hercules-2.com/

[9] Shipping world \& Shipbuilder (2004) Vol. 205, pp. 85.

[10] https://www.nyk.com/english/csr/envi/ecoship/

[11] DNV (2012), "Fuel Cells for Ships, Research and Innovation Position Paper", pp. 18

[12] https://www.ship-technology.com/projects/viking-lady/

[13] https://en.wikipedia.org/wiki/T\%C3\%BBranor_PlanetSol ar

[14] https://en.wikipedia.org/wiki/Beluga_Shipping

[15] https://www.marinetraffic.com/en/ais/details/ships/shipid :385113/mmsi:319091000/imo:1009089/vessel:BELUG A

[16] http://dione.lib.unipi.gr/xmlui/bitstream/handle/unipi/651 3/MN08034.pdf?sequence $=1 \&$ isAllowed $=y$ 